\title{
Innovative Ultrasound-Assisted Approaches towards Reduction of Heavy Metals and Iodine in Macroalgal Biomass
}

\author{
Estefanía Noriega-Fernández ${ }^{1,2}{ }^{*} * \mathbb{C}$, Izumi Sone ${ }^{1}$, Leire Astráin-Redín ${ }^{3}$, Leena Prabhu ${ }^{1}$, Morten Sivertsvik ${ }^{1}{ }^{(0)}$, \\ Ignacio Álvarez ${ }^{3}(\mathbb{D})$ and Guillermo Cebrián ${ }^{3}(\mathbb{0})$ \\ 1 Department of Processing Technology, Nofima, NO-4021 Stavanger, Norway; Izumi.Sone@Nofima.no (I.S.); \\ leena.prabhu@nofima.no (L.P.); Morten.Sivertsvik@Nofima.no (M.S.) \\ 2 European Food Safety Authority, Via Carlo Magno 1A, 43126 Parma, Italy \\ 3 Departamento de Producción Animal y Ciencia de los Alimentos, Facultad de Veterinaria, \\ Instituto Agroalimentario de Aragón-IA2-(Universidad de Zaragoza-CITA), 50013 Zaragoza, Spain; \\ astrain@unizar.es (L.A.-R.); ialvalan@unizar.es (I.Á.); guiceb@unizar.es (G.C.) \\ * Correspondence: estefania.noriega@nofima.no; Tel.: +47-47706088
}

check for updates

Citation: Noriega-Fernández, E.; Sone, I.; Astráin-Redín, L.; Prabhu, L.; Sivertsvik, M.; Álvarez, I.; Cebrián, G. Innovative Ultrasound-Assisted Approaches towards Reduction of Heavy Metals and Iodine in Macroalgal Biomass. Foods 2021, 10, 649. https://doi.org/10.3390/ foods10030649

Academic Editor: Reza Ovissipour

Received: 12 February 2021

Accepted: 17 March 2021

Published: 19 March 2021

Publisher's Note: MDPI stays neutral with regard to jurisdictional claims in published maps and institutional affiliations.

Copyright: (c) 2021 by the authors. Licensee MDPI, Basel, Switzerland. This article is an open access article distributed under the terms and conditions of the Creative Commons Attribution (CC BY) license (https:// creativecommons.org/licenses/by/ $4.0 /)$

\begin{abstract}
The aim of this work was to evaluate the potential of ultrasound (US), alone or in combination with mild heating and/or EDTA towards reduction of As, Cd, I, and Hg content of Laminaria hyperborea. Concentrations of As, Cd, I, and $\mathrm{Hg}$ of $56.29,0.596,7340$, and $<0.01 \mathrm{mg} \mathrm{kg}^{-1}$ of dry weight, respectively, were found in L. hyperborea blades. Treatment with US at $50{ }^{\circ} \mathrm{C}$ increased approx. 2-fold the amount of As released, although did not affect significantly the content of Cd or I, as compared to control (no US) samples. Reducing the temperature to $8{ }^{\circ} \mathrm{C}$ significantly decreased the effect of US, but heating at $80^{\circ} \mathrm{C}$ did not cause a significant effect as compared to treatments at $50{ }^{\circ} \mathrm{C}$. On the other hand, treatment with $0.1 \mathrm{~N}$ EDTA at $50^{\circ} \mathrm{C}$ enhanced the percentage of $\mathrm{Cd}$ released by approximately 7 -fold, regardless of sonication. In the present work, the combination of US and EDTA at $50{ }^{\circ} \mathrm{C}$ for $5 \mathrm{~min}$ led to a significant reduction of the As (32\%), Cd (52\%) and I (31\%) content in L. hyperborea, thus improving the product's safety for consumers.
\end{abstract}

Keywords: arsenic; cadmium; iodine; EDTA; brown macroalgae; Laminaria hyperborea; nonthermal technologies; mild heat; hurdle technology

\section{Introduction}

Seaweeds have constituted a very relevant and recognized part of the diet in certain parts of the world, such as Japan, China and Korea, for centuries or even millennia [1]. Their use as food ingredients has recently gained attention in Western countries such as Europe and the US [2], which has been attributed to the rising popularity of Asian cuisine and the Western-consumers' perception of seaweeds as a "healthy superfood" [3,4]. Nowadays, the annual production of algae for direct (sea vegetables) or indirect (phycocolloids) human consumption is estimated to be around 2,000,000 tons (dry matter) [5] with brown macroalgae being the most consumed macroalgae species $(66.5 \%)$, followed by red $(33 \%)$ and green (5\%) seaweeds [6].

Seaweeds are rich in vitamins, minerals and essential trace elements, polyunsaturated fatty acids, bioactive metabolites, proteins, polysaccharides, and dietary fiber [7]. Furthermore, health-promoting effects have been associated to direct seaweed consumption and the use of their extracts/components as processing aids (e.g., as hydrocolloids, emulsifiers and/or gelling agents) and dietary supplements [5,7-11]. However, their substantial bio-sorption and bio-accumulation capacity [12], particularly that of brown algae species such as Laminaria hyperborea, may increase the dietary exposure to potentially harmful compounds. Among them, heavy metals such as inorganic arsenic (iAs) and cadmium (Cd), and the essential micronutrient iodine (I), whose excessive intake may lead to adverse health effects [13], have been reported as major chemical hazards associated to seaweed 
consumption in the European seaweed chain [3]. Thus, several studies have reported high levels of iAs, Cd and I in seaweed and seaweed-based food products, which in many cases exceeded the recommended or allowed levels in different countries [14-20]. Nevertheless, it also should be noted that levels of heavy metals and iodine in seaweeds have been reported to substantially vary across species, location, season, and growth-related factors [21-24].

Different post-harvest processing strategies have been assessed to reduce the content of undesirable elements in seaweeds. Traditional methods include rinsing, boiling, fermentation and drying. Rinsing in water has been shown to reduce iAs and/or I levels [15,23,25-27], although no significant effects have otherwise been reported in a few studies [28]. Temperature seems to play a key role as reductions in I and As up to $94 \%$ have been observed after blanching or boiling $[17,25,29]$. For instance, the Belgian Superior Health Council has recommended boiling as an effective method for iAs removal in seaweeds, although the relatively high levels of As released into the water may limit further uses of the cooking media [30]. Similarly, fermentation has also been demonstrated as an effective strategy to reduce the content of $\mathrm{Hg}, \mathrm{Cd}$ and I in sugar kelp [31]. However, the efficacy of these methods seems to vary widely with operational conditions, seaweeds species, etc., leading most of them to undesirable changes in the nutritional and organoleptic properties of seaweeds [32-36].

In the last decade, promising potential of innovative nonthermal technologies, such as ultrasound (US), has been demonstrated for green extraction of algal bioactives (e.g., carotenoids, polyphenols, polysaccharides), with improved process cost-effectiveness and recovery yield, and enhanced techno-functionality and bioactivity of end products [37]. US, typically combined with mild heating, acid or alkali surfactants, has also been proved as an effective preparative step for improved extraction of heavy metals and iodine from seaweeds towards further quantification via e.g., Inductively Coupled Plasma Optical Emission Spectrometry (ICP-OES) or Inductively Coupled Plasma Mass Spectrometry (ICPMS) [38-42]. However, apart from these applications that require high US intensities in order to disrupt seaweed cells, this technology can also be used to enhance mass and energy transfer processes when applied at much lower intensities. This would limit its impact in the organoleptic properties of seaweeds, enabling the production of seaweed-based products with enhanced quality attributes (e.g., texture, color, flavor) while ensuring food safety and/or extended shelf-life, and would also facilitate its industrial implementation because of the lower associated costs [43-45]. However, to the knowledge of the authors, the potential of US to reduce the content of heavy metals and I in food matrices, and particularly in seaweeds, has been hardly investigated. Very promising results were reported by Condón-Abanto et al. [46], who demonstrated that the combination of US and mild heating effectively reduced the content of $\mathrm{Cd}$ in edible crab but, still, further studies focusing on process characterization and optimization on relevant seaweed matrices, as well as synergistic and multitarget combination with relevant hurdles (e.g., temperature, EDTA), are required towards technology validation and eventually, industry uptake.

Therefore, the aim of this work was to evaluate the potential of US, alone or in combination with mild heating and/or EDTA, a food-grade chelating agent with potential to desorb metal ions from macroalgae [47], to reduce the content of iAs, Cd, $\mathrm{Hg}$, and I in wild-harvested L. hyperborea.

\section{Materials and Methods}

\subsection{Raw Material}

Wild Laminaria hyperborea samples were kindly supplied by Dolmøy House of Seafood AS (Frøya, Norway). Whole mature plants, harvested in May 2020 at $63^{\circ} 41^{\prime} 49.2^{\prime \prime} \mathrm{N}$ $8^{\circ} 49^{\prime} 22.7^{\prime \prime} \mathrm{E}$, were shipped overnight under refrigerated conditions. Immediately after reception, both stipe and holdfast of selected plants were removed with a sterile scalpel and discarded. The 2-3 cm-side square-shaped samples were aseptically cut from central undamaged areas of the remaining blades, then placed into sterile glass jars closed with aluminum lids $\left(5.0 \pm 0.2 \mathrm{~g}\right.$ total wet weight per jar) and stored at $4{ }^{\circ} \mathrm{C}$ overnight. 


\subsection{Treatment Conditions}

Glass jars with $\approx 5 \mathrm{~g}$ L. hyperborea samples were filled in with $100 \mathrm{~mL}$ Milli-Q water tempered as appropriate, and treated at 8,50 or $80^{\circ} \mathrm{C}$ for 5 and 30 min either in a thermostatic water bath (Anritsu HD-1250K Thermometer, Atsugi, Japan) or an ultrasonic water bath operating at $68 \mathrm{kHz}$ and $500 \mathrm{~W}$ (BT 130H, UPCORP, Freeport, IL, USA), with a nominal specific power of $0.016 \mathrm{~W} / \mathrm{g}$. Likewise, $5 \mathrm{~g}$ macroalgae samples were exposed to $100 \mathrm{~mL} 0.1$ N EDTA disodium salt (Sigma-Aldrich, Darmstadt, Germany) for 5 and $30 \mathrm{~min}$ at $50{ }^{\circ} \mathrm{C}$, both in presence and absence of sonication. Under the assayed conditions, the final temperature of the treatment media increased less than $5{ }^{\circ} \mathrm{C}$ as a consequence of the application of ultrasound (data not shown).

After the treatment, seaweed samples were recovered from the rinsing media and then dehydrated at $105^{\circ} \mathrm{C}$ in a convection drying oven (P-model Digitronic Selecta, Barcelona, Spain). After weighing, dehydrated samples were ground and stored in hermetic tubes until further analysis of iodine and heavy metals.

The content of heavy metals (arsenic, cadmium and mercury) and iodine was also analyzed in the corresponding rinsing media. $\mathrm{HNO}_{3}$ (J.T. Baker, Philipsburg, New Jersey, USA) or TMAH ( $25 \% w / w$, Sigma-Aldrich) were added, respectively, to those samples intended for analysis of heavy metals and iodine, at a final concentration of $5 \% v / v$. The samples were then frozen at $-30{ }^{\circ} \mathrm{C}$ until further analysis.

\subsection{Cadmium, Mercury and Total Arsenic Analysis}

The amount of cadmium, mercury and total arsenic in both seaweed and rinsing media samples was measured by ICP-MS. For seaweed samples, $0.2 \mathrm{~g}$ of dehydrated seaweed was diluted in MilliQ-water and incubated at room temperature for $20 \mathrm{~min}$ in microwave-resistant tubes (MarsX-press Plus Wessel, CEM Corporation). Then, $5 \mathrm{~mL}$ $\mathrm{HNO}_{3}$ was added to the tubes, which were sealed right after. Samples were digested in a microwave system using a 10-min heating ramp at $800 \mathrm{~W}$ and maintained at $200{ }^{\circ} \mathrm{C}$ for $10 \mathrm{~min}$. Then, the samples were cooled, filtered $(0.45 \mu \mathrm{m})$ and adequately diluted prior to injection in the ICP-MS equipment (Elan DRC-e, Perkin-Elmer, Rodgau, Germany). The ICP-MS instrumental settings are described in Condón-Abanto et al. [46]. Samples of treatment media were processed in a similar way, but $5.0 \mathrm{~mL}$ of sample, instead of $0.2 \mathrm{~g}$ of dehydrated sample, was directly mixed with $5 \mathrm{~mL} \mathrm{HNO}_{3}$ within the microwave tubes before the digestion step.

\subsection{Iodine Analysis}

The amount of iodine was measured by means of ICP-OES. For seaweed samples, $0.2 \mathrm{~g}$ of dehydrated seaweed was diluted in $5 \mathrm{~mL}$ MilliQ water within gas-tight glass tubes (Sovirell tube). TMAH (25\% $w / w$, Sigma-Aldrich) was added to a final concentration of $5 \% v / v$ and tubes were closed with screw caps and PTFE-coated rubber sealing. Samples were digested in a convective oven at $90^{\circ} \mathrm{C}$ for $3 \mathrm{~h}$. Then, samples were cooled, filtered $(0.45 \mu \mathrm{m})$ and adequately diluted before being injected in the ICP-OES equipment (Elemental IRIS Intrepid II XLD, Thermo Electron, Waltham, MA, USA). Samples of treatment media were processed similarly, but $5.0 \mathrm{~mL}$ of the treatment medium, instead of $0.2 \mathrm{~g}$ of dehydrated sample, was added to the tube before the addition of TMAH and the digestion step.

\subsection{Determination of Removal Efficacy}

The results obtained from the seaweed analysis were expressed as $\mathrm{mg}$ of $\mathrm{As}, \mathrm{Cd}, \mathrm{Hg}$, and I per kg of dry weight (ppm). The amount of each compound released was calculated using Equation (1):

$$
\% \text { substance released }=\frac{[\text { substance }]_{\text {water }} \times V \times 100}{[\text { substance }]_{\text {seaweed }} \times W}
$$

where [substance $]_{\text {water }}$ represents the concentration of the substance in $\mathrm{mg} / \mathrm{L}$ measured in the treatment medium; $V$, is the volume of treatment medium $(0.1 \mathrm{~L})$; $\left[\right.$ substance $_{\text {seaweed }}$ is 
the concentration of the substance in $\mathrm{mg} / \mathrm{kg}$ dry weight in the fresh (untreated) seaweed and $W$ is the dry weight $(\mathrm{kg})$ of the fresh seaweed sample.

\subsection{Statistical Analysis}

GraphPad PRISM software (Graph Software, San Diego, CA, USA) was used for statistical analyses (analysis of variance and Student's $t$-test) $(p=0.05)$. All the determinations were performed in triplicate.

\section{Results}

\section{1. $\mathrm{As}, \mathrm{Cd}, \mathrm{Hg}$, and I Content in Untreated, Wild-Harvested L. hyperborea}

The content of As (total), Cd, $\mathrm{Hg}$ and I was determined in untreated, wild-harvested L. hyperborea samples in order to set a biological baseline for further estimations of the removal efficacy of US alone or in combination with mild heating and EDTA. Despite the content of $\mathrm{Hg}$ being below the IPC-MS detection limit, the levels determined for the remaining compounds fall within the concentration ranges reported in the literature for L. hyperborea and other brown macroalgae [16,23,48-51]. Variability in the content of As, $\mathrm{Cd}, \mathrm{Hg}$, and I in L. hyperborea and, in general, seaweeds, has been substantially reported. Geographical location, seasonality, salinity, and temperature of the surrounding water, depth, and developmental determinants, such as maturity and blade morphology and size, among others, account for such variability $[23,48,51-55]$. Thus, in preliminary experiments, up to $56 \%$ variability in the content of Cd (data not shown) was found in L. hyperborea samples collected within a one-month span across the harvesting season. Considering such a high fluctuation in the raw material, the present work was conducted with mature L. hyperborea specimens with similar morphological features (i.e., blade size and width), which were harvested simultaneously from the same location. Nonetheless, the biological variability (standard deviation of three replicates) in the content of heavy metals and iodine in the raw samples accounted for more than $10 \%$ of the mean values for all the elements studied, and up to $23.7 \%$ for the I content, which was attributed to the significant variability across specimens. To avoid interferences in the analytical determinations derived from such a high biological variability in the raw material, the amount of heavy metals and iodine released into the rinsing media was measured rather than the remaining levels in the blades after the respective treatments, as already described elsewhere [46].

In the present study, total As levels in L. hyperborea blades $(56.3 \pm 5.1 \mathrm{mg} / \mathrm{kg})$, similar to those reported for L. digitata (36.0-131.0 mg/kg of dry weight), were however higher than the values found in other macroalgae species [16,56-58] but lower (5-fold) than those reported for Hijiki [29]. Arsenic is a metalloid present in the environment in different inorganic (iAs) and organic forms, originating from natural and anthropogenic sources [59]. Due to its high concentration (more than 10-fold higher than the content in vegetables, grains and meats), seaweed intake greatly contributes to the dietary exposure to As $[18,26,60]$. For instance, the Korea Food and Drug Administration reported that seaweed accounted for the second highest source of exposure to total arsenic via food (20\%) in Korea, despite seaweeds ranking 13th out of 17 items in the daily per capita intake, with $22.4 \mathrm{~g} /$ person/day [29]. iAS forms (arsenate V (Asv) and arsenite III (AsIII)) are acknowledged to be more toxic than organic forms [61] and, although in the majority of species most of the arsenic exists in the form of nontoxic arsenosugars, iAs can account for up to $60-73 \%$ of the total As for some of them $[60,62]$. Assuming that only $10 \%$ of the total As in the samples would be in inorganic form (up to $50 \%$ has been reported for this particular species [57]), the As content reported in the present work would exceed the limit of $3 \mathrm{mg} / \mathrm{kg} \mathrm{dw}$ iAs recommended by the French Food Safety Authority in edible seaweeds [63,64].

The content of $\mathrm{Cd}$ in untreated L. hyperborea samples determined in the present study $(0.6 \pm 0.01 \mathrm{mg} / \mathrm{kg})$ is lower than the levels reported for L. japonica $(0.45-0.80 \mathrm{mg} / \mathrm{kg})$ [26], but still well-above the maximum limits set for seaweed products by the Food Safety Authority in France $(0.5 \mathrm{mg} / \mathrm{kg}$ of dry weight) and Australia/New Zealand $(0.2 \mathrm{mg} / \mathrm{kg}$ of dry weight) [65]. However, these concentrations would be reasonably close to the 
maximum permitted levels set by the Food Safety Authority in China (1.0 mg/ kg) [65] and in Regulation (EC) 1881/2006 (3.0 mg/kg of wet weight) for food supplements consisting exclusively or mainly of dried seaweed, products derived from seaweed, or of dried bivalve molluscs [3].

Although the content of $\mathrm{Hg}$ in L. hyperborea was below the detection limit $(<0.01 \mathrm{mg} / \mathrm{kg})$ of the analytical technique (ICP-MS), and thus excluded for further analysis, the concentration range coincides with values reported for brown seaweeds [16]. Moreover, the ICP-MS method's performance criteria would still fall far below the maximum permitted level $(0.1 \mathrm{mg} / \mathrm{kg}$ ) set by the Regulation (EC) 1881/2006 in food supplements and by the French Food Safety Authority in edible seaweeds [3].

Finally, the I values determined in this work $(7340 \pm 1744 \mathrm{mg} / \mathrm{kg})$ largely exceed the maximum limit recommended by the French Food Safety Authority $(2000 \mathrm{mg} / \mathrm{kg} \mathrm{dw})$ in edible seaweeds [66]. The substantial accumulation of this micronutrient in brown macroalgae and particularly Laminariales (>30,000-fold higher than environmental levels) has been attributed to the high content of alginate and sulphated polysaccharides and the presence of cell-wall haloperoxidases [16,48,51]. Despite the benefits for iodine-deficient populations, highly susceptible to goiter and hypothyroidism, excessive intake of iodine can however cause adverse health effects such as dysfunctions of the thyroid gland $[67,68]$. Thus, dietary reference values for I, expressed as adequate intake (AI), have been set as $150 \mu \mathrm{g} /$ day for adults, 70-100 $\mu \mathrm{g}$ /day for infants and children, and $200 \mu \mathrm{g} / \mathrm{day}$ for pregnant and lactating women [68]. At the same time, tolerable upper intake levels of $600 \mu \mathrm{g} /$ day for adults, including pregnant and lactating women, and 200-500 $\mathrm{gg} / \mathrm{day}$ for children, have been recommended. However, the average dietary iodine intake due to the ingestion of seaweeds has been estimated for instance in Japan as 1-3 mg/day, which significantly exceeds tolerable upper levels [69].

In conclusion, the relatively high content of As, $\mathrm{Cd}$ and I in brown macroalgae, as confirmed in the present work, seems to exceed maximum permitted levels and substantially contribute to the dietary intake of such potentially harmful compounds, which is urging the implementation of sustainable and multitarget removal strategies towards improved food safety of seaweeds and products thereof.

\subsection{Effect of US on As, Cd and I Removal from L. hyperborea Blades}

The potential of US for increasing and/or accelerating the release of As, Cd and I from L. hyperborea blades was initially studied at $50{ }^{\circ} \mathrm{C}$, which has been reported as the optimal temperature for US-assisted removal of $\mathrm{Cd}$ in crab claws [46]. Moreover, this value is very close to the minimum temperature $\left(45^{\circ} \mathrm{C}\right)$ necessary for significantly reducing the iodine content of Sacharrisima lattisima after soaking treatments [25]. As observed in Figure 1a, US treatment significantly increased the amount of As released into the medium from $L$. hyperborea blades, almost doubling after $5 \mathrm{~min}$ the levels released in absence of US (27.4\% vs. $15.2 \%$ ). Longer US treatment time $(30 \mathrm{~min})$ did not significantly improve the removal efficacy for As, although a slight increase in average values (not statistically significant) was observed for control samples in absence of US. However, the amount of As released after $30 \mathrm{~min}$ at $50{ }^{\circ} \mathrm{C}$ was still significantly higher for US-treated samples. Regarding $\mathrm{Cd}$ and I, no significant differences in the removal efficacy were observed for sonicated and control samples, independently of the treatment time (Figure 1b,c).

These results might be explained on the basis of, on one hand, the different mechanisms of bio-absorption and bio-accumulation in macroalgal biomass and, on the other hand, the mechanism of action of US. Thus, chelation is the main sequestration mechanism for $\mathrm{Cd}$, whereas adsorption and metabolism-regulated active uptake have been reported for As [70,71]. Interestingly, As might be stored in inorganic form ( $>50 \%$ for some species) or most commonly as nontoxic arsenosugars, which depends on the particular macroalgae species. Moreover, interspecies differences in cell-wall composition and chemistry seem to play a major role in the biphasic accumulation of heavy metals (e.g., As vs. Cd), which is regulated first by rapid extracellular adsorption or passive intracellular uptake, and there- 
after by metabolism-dependent incorporation and excretion processes. For instance, higher affinity for heavy metals has been reported in macroalgal biomass rich in carboxyl groups rather than sulphate groups in the cell wall [72]. These compositional differences across species might lead in some cases to most of the As and $\mathrm{Cd}(60-80 \%)$ being retained at the apoplast or surface [73]. Regarding iodine, 99\% content in Laminariales has been reported to be highly water soluble [74] since the majority would be occurring as noncovalently bound I- in the apoplast outside the cells [75].

As

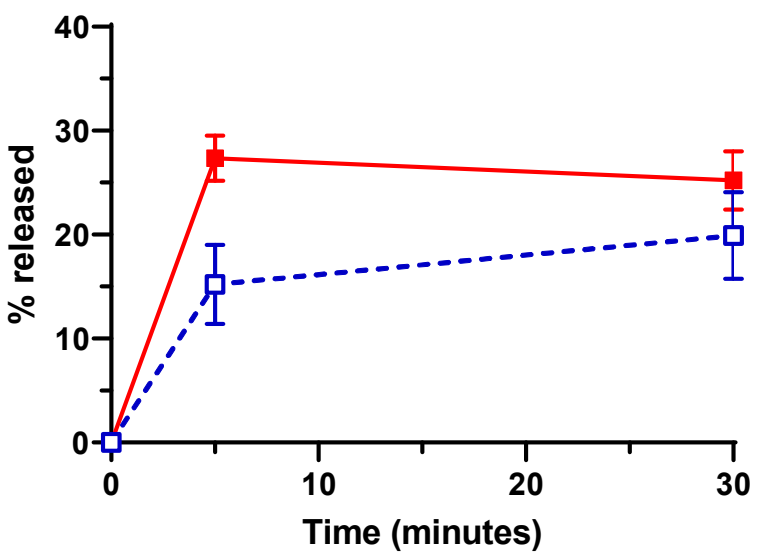

(a)
Cd

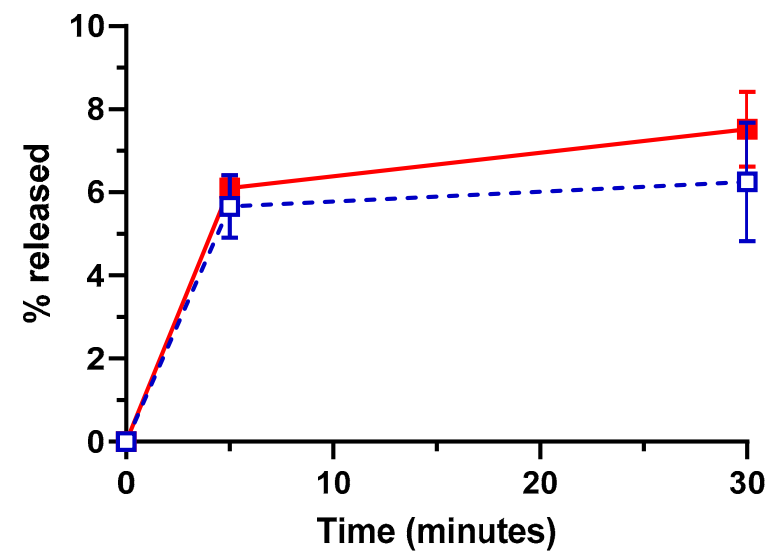

(b)

I

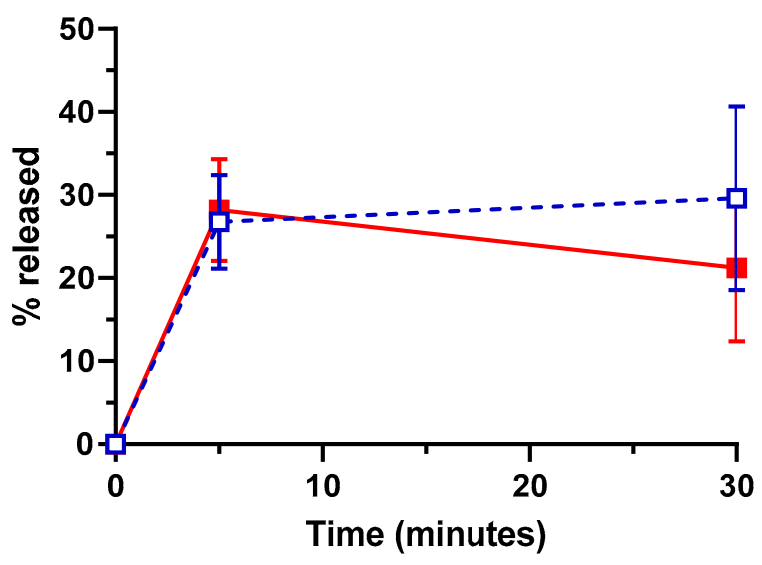

(c)

Figure 1. Percentage of arsenic (As) (a), cadmium (Cd) (b) and iodine (I) (c) released from Laminaria hyperborea blades after Ultrasound (US) (red filled symbols, continuous lines) and Control treatments (no US; blue empty symbols, discontinuous lines). Treatment temperature: $50^{\circ} \mathrm{C}$. Error bars correspond to the standard deviations.

Considering the low US intensity applied, breakdown of seaweed cell walls/ membranes or covalent bounds is not expected, as structural modifications of the blades were not observed after the US treatments at $50{ }^{\circ} \mathrm{C}$ (data not shown). Moreover, the potential contribution of US-generated free radicals to the release of As, Cd and I is expected to be negligible due to the low US intensity and frequency $(68 \mathrm{kHz})$ applied. Therefore, US treatment would only enhance the release of those elements located in the apoplast or surface of the blades and not covalently bound to other molecules (unless the whole molecule is released to the medium). Noncovalently bound I and inorganic As would then leach 
rapidly to the treatment medium (distilled water), whereas chelated Cd will not be released to the same extent. The present study supports the above-mentioned assumptions, with $30 \%$ removal efficacy for I and As after US treatment, as compared to $9 \%$ for Cd. In addition, US might not have a significant effect on I release, as compared to the soaking/washing treatment itself (with no US), given its high solubility in water. As the results obtained for As suggest, US treatment most likely will not lead to higher decontamination level but otherwise accelerate desorption kinetics. Therefore, a more pronounced effect of US on the amount of I released, as compared to control samples, might have been observed at shorter treatment times. Finally, the apparent inefficacy of US towards Cd and I release, as compared to control samples, might be attributed as well to the low US intensity applied in this work, which leaves room for improved US decontamination efficacy in further works.

The outcomes of the present study differ from the results presented by Condón-Abanto et al. [46], where a linear increase in the removal efficacy for Cd was reported in crab claws towards increasing US treatment time, eventually achieving 9-fold higher values than those in control samples. These differences may be attributed to different US operational conditions (e.g., frequency and mode of application) and treatment media (tap vs. distilled water), as well to the different $\mathrm{Cd}$ bioaccumulation mechanisms in seaweeds and crustaceans and to the differences between animal and seaweed cell structure/envelopes. Further studies are required in order to shed light on the release mechanisms for As and $\mathrm{Cd}$, as well as to determine the specific effect of US on the removal of inorganic As.

\subsection{Influence of Treatment Temperature on As, Cd and I Removal by US}

Treatment temperature has been demonstrated to play a major role in the release of undesirable compounds from seaweeds [15] and to enhance US food preservation efficacy [76]. Thus, the influence of treatment temperature on As, Cd and I release after US treatments was studied at 8,50 and $80{ }^{\circ} \mathrm{C}$ for 5 and $30 \mathrm{~min}$. As observed in Figure 2, a temperature rise from 8 to $50{ }^{\circ} \mathrm{C}$ resulted in a significant $(p<0.05)$ increase in the removal of As and Cd for both 5 and 30 min US treatments, whereas the longest treatment time was needed to enhance significantly the I released. However, no significant differences in As, $\mathrm{Cd}$ and I release were found when US treatments were carried out at 50 or $80{ }^{\circ} \mathrm{C}$, regardless of the treatment time, which might be attributed to (1) the reduced energy transferred by cavitation when the vapor tension of the liquid increases [77,78], and (2) the limited effect of US on Cd and I release. It is noteworthy that, in absence of US treatment, the temperature increase from 50 to $80{ }^{\circ} \mathrm{C}$ did not improve either the release of these compounds from L. hyperborea blades (data not shown). Although Condón-Abanto et al. [46] also reported $50{ }^{\circ} \mathrm{C}$ as the optimal temperature for US removal of $\mathrm{Cd}$ in edible crab, the high biological variability across macroalgal specimens might have dampened the actual effect of the treatment temperature, at least for $\mathrm{Cd}$ and I. On the other hand, US treatment time (5 or $30 \mathrm{~min}$ ) only played a significant role at $8{ }^{\circ} \mathrm{C}$, with regards to the amount of As and I released. Therefore, US treatments as short as $5 \mathrm{~min}$ would lead to the maximum decontamination efficacy, provided that the temperature is $\geq 50{ }^{\circ} \mathrm{C}$, which would save time and resources and thus, facilitate the industrial implementation of this technology. 
As

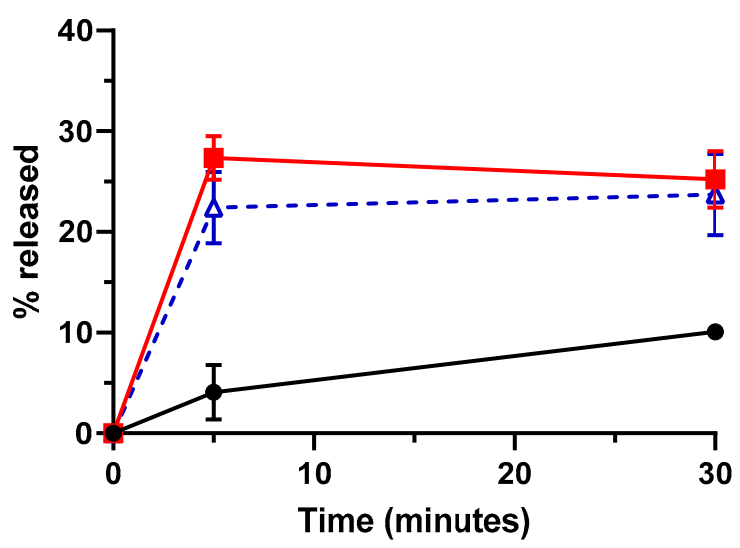

(a)
Cd

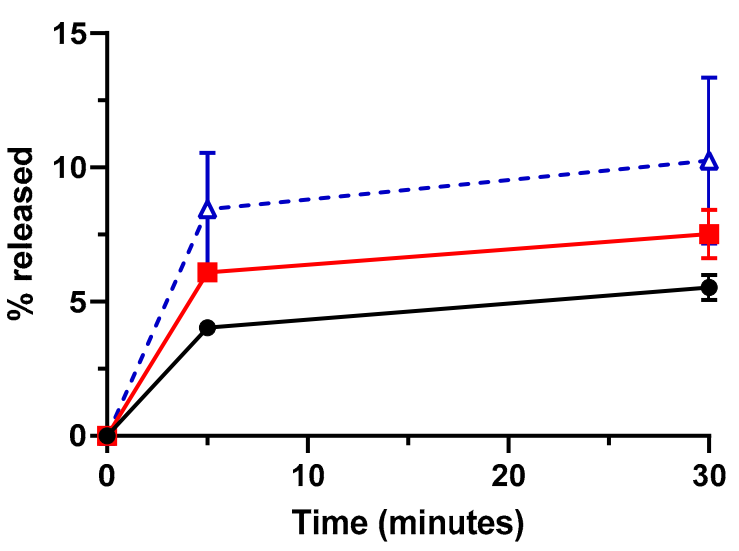

(b)

I

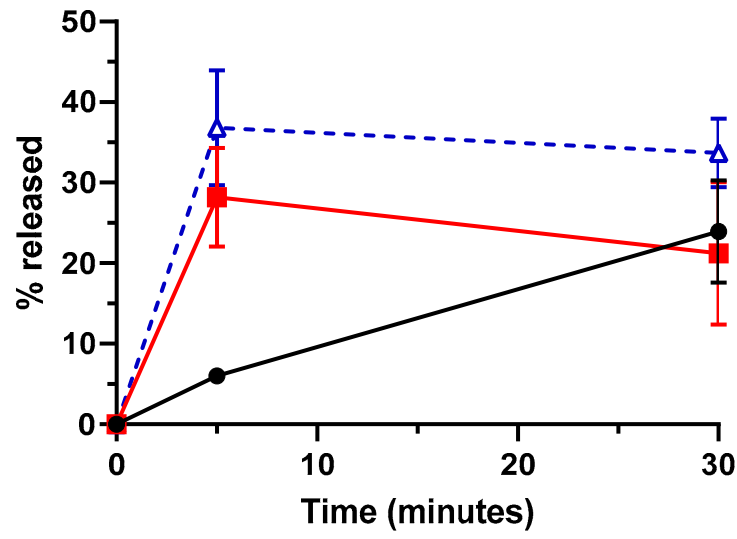

(c)

Figure 2. Influence of treatment temperature on the percentage of arsenic (As) (a), cadmium (Cd) (b) and iodine (I) (c) released from Laminaria hyperborea blades after Ultrasound treatments. Treatment temperature: $8{ }^{\circ} \mathrm{C}(\bullet), 50{ }^{\circ} \mathrm{C}(\boldsymbol{\square})$ and $80^{\circ} \mathrm{C}(\triangle)$. Error bars correspond to the standard deviations.

\subsection{Influence of the Addition of EDTA on As, Cd and I Removal by US}

The potential of US treatment in combination with EDTA $(0.1 \mathrm{~N})$ for the removal of As, Cd and I is shown in Figure 3. Since (1) the removal efficacy for As and Cd significantly decreased at $8{ }^{\circ} \mathrm{C}$ and (2) no significant differences were found in the \% released at 50 and $80^{\circ} \mathrm{C}$, the former temperature was selected for these trials. The addition of EDTA resulted in a significant increase (between 6.5- and 8.4-fold) in the amount of $\mathrm{Cd}$ released, regardless of sonication and treatment time. This increase was even slightly higher for US treatments. Thus, although no significant differences in the amount of $\mathrm{Cd}$ released were found between control and US-treated samples in absence of EDTA, they were found $(p<0.05)$ for $5 \mathrm{~min}$ treatments when this chelating agent was added to the treatment media (Figure $3 b$ ). 
As

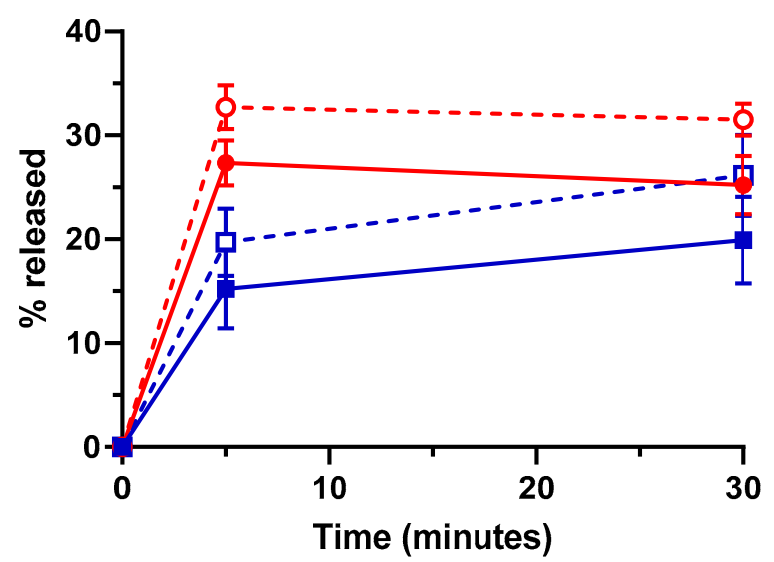

(a)
Cd

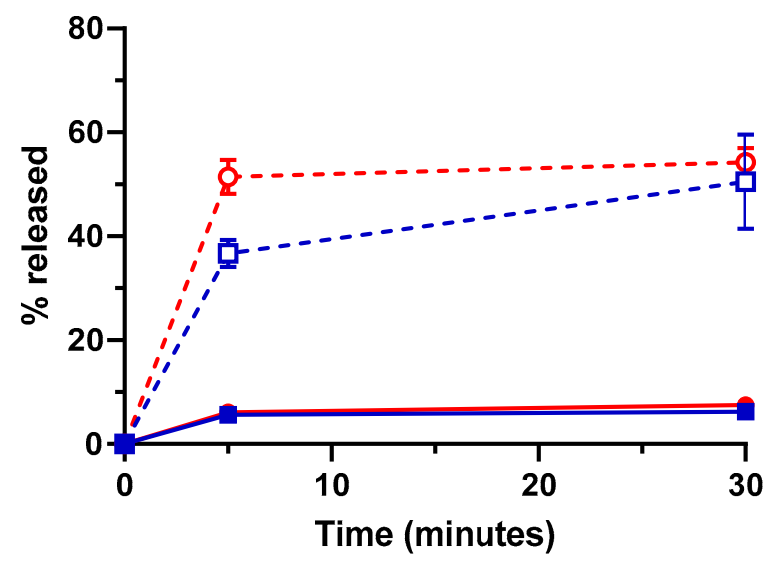

(b)

I

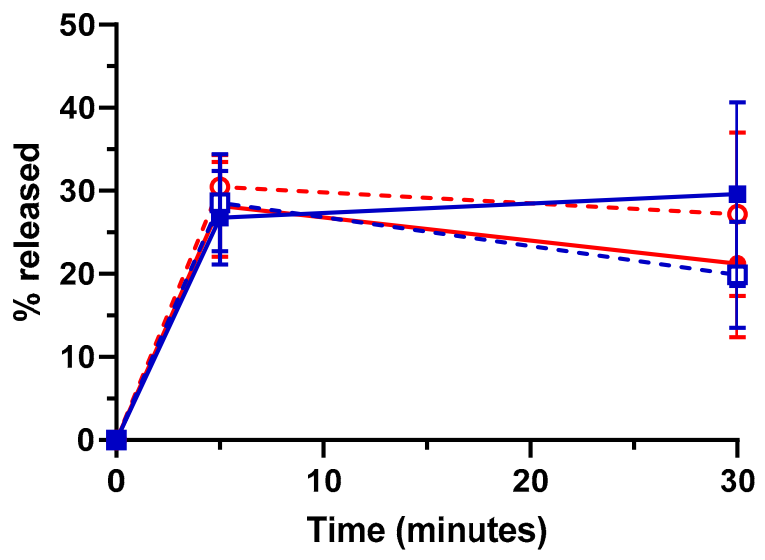

(c)

Figure 3. Percentage of arsenic (As) (a), cadmium (Cd) (b) and iodine (I) (c) released from Laminaria hyperborea blades after Ultrasound (US) (red symbols and lines: •, ○) and Control treatments (no US; blue symbols and lines: $\mathbf{\square}, \square$ ). Treatments were carried out with (empty symbols, discontinuous lines: $\bigcirc--, \square--$ ) or without (filled symbols, continuous lines: $\bullet$ the addition of EDTA $(0.1 \mathrm{~N})$. Treatment temperature: $50^{\circ} \mathrm{C}$. Error bars correspond to the standard deviations.

Although in a less pronounced manner, addition of EDTA also increased the amount of As released (1.2- and 1.3-fold; Figure 3a), although did not improve the removal efficacy for I, irrespective of sonication and treatment time (Figure 3c). EDTA is a strong chelating agent approved in the EU as a food additive (E385) and in the United States (GRAS status). Its high level of complexing capacity with regard to heavy metals [79] would explain the increased release of Cd from L. hyperborea blades, thus supporting chelation as the main macroalgae sequestration mechanism for the $\mathrm{Cd}^{+2}$ cation. On the other hand, the limited effect of EDTA on As could be attributed to the desorption of organic arsenic species not being affected by EDTA addition, since coprecipitation only occurs with inorganic species [80]. Strong chelating agents such as EDTA have been reported to break down cellulose polymers and degrade macroalgal cell wall [12,29], thus leading to complete solubilization of the biomass and release of both anionic and cationic species. However, no biomass loss was observed upon the EDTA addition in this study, which would explain why the release of I was not affected by EDTA addition. 


\section{Conclusions}

Accumulation of As, Cd and I in brown macroalgae stands as a major food safety hazard restraining the broad utilization of this valuable nutrient source in food applications [15,81]. The relatively high content of As, Cd and I in brown macroalgae, as confirmed in the present work, seems to exceed maximum permitted levels and substantially contribute to the dietary intake of such potentially harmful compounds, which is urging the implementation of sustainable and multitarget removal strategies towards improved food safety of seaweeds and products thereof. In the present study, the combined application of US, mild heating $\left(50^{\circ} \mathrm{C}\right)$ and EDTA $(0.1 \mathrm{~N})$ for $5 \mathrm{~min}$ led to $32 \%$ and $52 \%$ release of As and $\mathrm{Cd}$, respectively, from L. hyperborea blades without affecting the efficacy of soaking treatments (at the same temperature) towards reduction of I content. To the knowledge of the authors, this is a pioneering study demonstrating the potential of combined US, EDTA and mild heat for reducing the As, Cd and I content in seaweed. However, further work on process optimization, with particular emphasis on US intensity and frequency and the rinsing media, as well as interspecies validation is required towards both maximum removal of As, Cd and I and minimum impact on nutritional and sensory quality of kelp.

Author Contributions: Conceptualization, E.N.-F., I.S., I.Á. and G.C.; methodology, E.N.-F., I.S., I.Á. and G.C.; formal analysis, G.C.; investigation, E.N.-F., I.S., L.A.-R. and L.P.; writing-original draft preparation G.C.; writing—review and editing, E.N.-F., I.S., L.A.-R., L.P., M.S., I.Á. and G.C.; supervision, E.N.-F., I.S., I.Á. and G.C.; project administration, E.N.-F., I.S. and G.C.; funding acquisition, E.N.-F., I.S. and M.S. All authors have read and agreed to the published version of the manuscript.

Funding: This research was funded by the Research Council of Norway (SeaVALUE project, 296697, 2019-2022).

Data Availability Statement: The data presented in this study are available on request from the corresponding author.

Acknowledgments: L.A.-R. gratefully acknowledges financial support for her studies provided by the "Ministerio de Educación y Formación Profesional". Authors would also like to acknowledge the use of Servicio General de Apoyo a la Investigación-SAI, Universidad de Zaragoza.

Conflicts of Interest: The authors declare no conflict of interest.

Disclaimer: The author Estefanía Noriega Fernández, is employed with the European Food Safety Authority (EFSA) in the Unit Nutrition that provides scientific and administrative support to the Panel on Nutrition, Novel Foods and Food Allergens in the area "Safety Assessment of Novel Foods". However, the present article is published under the sole responsibility of the authors E. Noriega Fernández, I. Sone, L. Astráin-Redín, L. Prabhu, M. Sivertsvik, I. Álvarez, G. Cebrián and may not be considered as an EFSA scientific output. The positions and opinions presented in this article are those of the author/s alone and are not intended to represent the views/any official position or scientific works of EFSA. To know about the views or scientific outputs of EFSA, please consult its website under http:/ / efsa.europa.eu.

\section{References}

1. Bocanegra, A.; Bastida, S.; Benedí, J.; Ródenas, S.; Sánchez-Muniz, F.J. Characteristics and Nutritional and Cardiovascular-Health Properties of Seaweeds. J. Med. Food. 2009, 12, 236-258. [CrossRef]

2. Holland, J. Seaweed on Track to Become Europe's Next Big Superfood Trend. Available online: https://www.seafoodsource. $\mathrm{com} /$ news / food-safety-health/seaweed-on-track-to-become-europe-s-next-big-superfood-trend (accessed on 6 July 2019).

3. Banach, J.L.; Hoek-van den Hil, E.F.; van der Fels-Klerx, H.J. Food Safety Hazards in the European Seaweed Chain. Compr. Rev. Food. Sci. Food. Saf. 2020, 19, 332-364. [CrossRef]

4. Food and Agriculture Organization of the United Nations. The Global Status of Seaweed Production, Trade and Utilization. Available online: http:/ /www.fao.org/in-action/globefish/publications/details-publication/en/c/1154074/ (accessed on 5 February 2021).

5. Fleurence, J. Seaweed as Food. In Seaweed in Health and Disease Prevention; Fleurence, J., Levine, I., Eds.; Academic Press: Cambridge, MA, USA, 2016; pp. 149-167. ISBN 978-0-12-802772-1. 
6. Lorenzo, J.M.; Agregán, R.; Munekata, P.E.S.; Franco, D.; Carballo, J.; Şahin, S.; Lacomba, R.; Barba, F.J. Proximate Composition and Nutritional Value of Three Macroalgae: Ascophyllum Nodosum, Fucus Vesiculosus and Bifurcaria Bifurcata. Mar. Drugs. 2017, 15, 360. [CrossRef]

7. Ganesan, A.R.; Tiwari, U.; Rajauria, G. Seaweed Nutraceuticals and Their Therapeutic Role in Disease Prevention. Food. Sci. Hum. Well. 2019, 8, 252-263. [CrossRef]

8. Roohinejad, S.; Koubaa, M.; Barba, F.J.; Saljoughian, S.; Amid, M.; Greiner, R. Application of Seaweeds to Develop New Food Products with Enhanced Shelf-Life, Quality and Health-Related Beneficial Properties. Int. Food Res. J. 2017, 99, 1066-1083. [CrossRef]

9. Cardoso, S.; Carvalho, L.; Silva, P.M.; Rodrigues, M.I.; Pereira, O.; Pereira, L. Bioproducts from Seaweeds: A Review with Special Focus on the Iberian Peninsula. Curr. Org. Chem. 2014, 18, 896-917. [CrossRef]

10. Circuncisão, A.R.; Catarino, M.D.; Cardoso, S.M.; Silva, A.M.S. Minerals from Macroalgae Origin: Health Benefits and Risks for Consumers. Mar. Drugs. 2018, 16, 400. [CrossRef]

11. Cardoso, S.M.; Pereira, O.R.; Seca, A.M.L.; Pinto, D.C.G.A.; Silva, A.M.S. Seaweeds as Preventive Agents for Cardiovascular Diseases: From Nutrients to Functional Foods. Mar. Drugs. 2015, 13, 6838-6865. [CrossRef]

12. Davis, T.A.; Volesky, B.; Mucci, A. A Review of the Biochemistry of Heavy Metal Biosorption by Brown Algae. Water. Res. 2003, 37, 4311-4330. [CrossRef]

13. European Union (EU) Recommendation (EU). 2018/464 of 19 March 2018 on the Monitoring of Metals and Iodine in Seaweed, Halophytes and Products Based on Seaweed. Off. J. Eur. Union 2018, 61, 16-18.

14. Scientific Committee on Food; Scientific Panel on Dietetic Products, Nutrition and Allergies; European Food Safety Authority (EFSA). Tolerable Upper Intake Levels for Vitamins and Minerals; Scientific Committee on Food; Scientific Panel on Dietetic Products, Nutrition and Allergies; European Food Safety Authority (EFSA): Parma, Italy, 2006.

15. Stévant, P.; Marfaing, H.; Duinker, A.; Fleurence, J.; Rustad, T.; Sandbakken, I.; Chapman, A. Biomass Soaking Treatments to Reduce Potentially Undesirable Compounds in the Edible Seaweeds Sugar Kelp (Saccharina Latissima) and Winged Kelp (Alaria Esculenta) and Health Risk Estimation for Human Consumption. J. Appl. Phycol. 2018, 30, 2047-2060. [CrossRef]

16. Biancarosa, I.; Belghit, I.; Bruckner, C.G.; Liland, N.S.; Waagbø, R.; Amlund, H.; Heesch, S.; Lock, E.-J. Chemical Characterization of 21 Species of Marine Macroalgae Common in Norwegian Waters: Benefits of and Limitations to Their Potential Use in Food and Feed. J. Sci. Food. Agric. 2018, 98, 2035-2042. [CrossRef]

17. Lüning, K.; Mortensen, L. European Aquaculture of Sugar Kelp (Saccharina Latissima) for Food Industries: Iodine Content and Epiphytic Animals as Major Problems. Bot. Mar. 2015, 58, 449-455. [CrossRef]

18. Besada, V.; Andrade, J.M.; Schultze, F.; González, J.J. Heavy Metals in Edible Seaweeds Commercialised for Human Consumption. J. Mar. Syst. 2009, 75, 305-313. [CrossRef]

19. Khaled, A.; Hessein, A.; Abdel-Halim, A.M.; Morsy, F.M. Distribution of Heavy Metals in Seaweeds Collected along MarsaMatrouh Beaches, Egyptian Mediterranean Sea. Egypt. J. Aquat. Res. 2014, 40, 363-371. [CrossRef]

20. Commission Regulation (EC). No 1881/2006 of 19 December 2006 Setting Maximum Levels for Certain Contaminants in Foodstuffs (Text with EEA Relevance). Off. J. Eur. Union 2006, 364, 5-24.

21. Żbikowski, R.; Szefer, P.; Latała, A. Distribution and Relationships between Selected Chemical Elements in Green Alga Enteromorpha Sp. from the Southern Baltic. Environ. Pollut. 2006, 143, 435-448. [CrossRef]

22. Brown, M.T.; Hodgkinson, W.M.; Hurd, C.L. Spatial and Temporal Variations in the Copper and Zinc Concentrations of Two Green Seaweeds from Otago Harbour, New Zealand. Mar. Environ. Res. 1999, 47, 175-184. [CrossRef]

23. Roleda, M.Y.; Marfaing, H.; Desnica, N.; Jónsdóttir, R.; Skjermo, J.; Rebours, C.; Nitschke, U. Variations in Polyphenol and Heavy Metal Contents of Wild-Harvested and Cultivated Seaweed Bulk Biomass: Health Risk Assessment and Implication for Food Applications. Food Control 2019, 95, 121-134. [CrossRef]

24. Brito, G.B.; de Souza, T.L.; Bressy, F.C.; Moura, C.W.N.; Korn, M.G.A. Levels and Spatial Distribution of Trace Elements in Macroalgae Species from the Todos Os Santos Bay, Bahia, Brazil. Mar. Pollut. Bull. 2012, 64, 2238-2244. [CrossRef]

25. Nielsen, C.W.; Holdt, S.L.; Sloth, J.J.; Marinho, G.S.; Sæther, M.; Funderud, J.; Rustad, T. Reducing the High Iodine Content of Saccharina Latissima and Improving the Profile of Other Valuable Compounds by Water Blanching. Foods 2020, 9, 569. [CrossRef]

26. Almela, C.; Clemente, M.J.; Vélez, D.; Montoro, R. Total Arsenic, Inorganic Arsenic, Lead and Cadmium Contents in Edible Seaweed Sold in Spain. Food. Chem. Toxicol. 2006, 44, 1901-1908. [CrossRef]

27. Brandon, E.F.A.; Janssen, P.J.C.M.; de Wit-Bos, L. Arsenic: Bioaccessibility from Seaweed and Rice, Dietary Exposure Calculations and Risk Assessment. Food Addit. Contam. Part A Chem. Anal. Control Expo. Risk Assess 2014, 31, 1993-2003. [CrossRef]

28. Nitschke, U.; Stengel, D.B. Quantification of Iodine Loss in Edible Irish Seaweeds during Processing. J. Appl. Phycol. 2016, 28, 3527-3533. [CrossRef]

29. Park, G.; Kang, D.; Davaatseren, M.; Shin, C.; Kang, G.-J.; Chung, M.-S. Reduction of Total, Organic, and Inorganic Arsenic Content in Hizikia Fusiforme (Hijiki). Food. Sci. Biotechnol. 2019, 28, 615-622. [CrossRef]

30. Superior Health Council Arsenic and Other Elements in Algae and Dietary Supplements Based on Algae, Superior Health Council. Available online: https://www.absym-bvas.be/images/spf_sante/Conseil_superieur_de_la_sante/CSS_9149.pdf (accessed on 8 January 2021). 
31. Bruhn, A.; Brynning, G.; Johansen, A.; Lindegaard, M.S.; Sveigaard, H.H.; Aarup, B.; Fonager, L.; Andersen, L.L.; Rasmussen, M.B.; Larsen, M.M.; et al. Fermentation of Sugar Kelp (Saccharina Latissima)—Effects on Sensory Properties, and Content of Minerals and Metal. J. Appl. Phycol. 2019, 31, 3175-3187. [CrossRef]

32. Blikra, M.J.; Løvdal, T.; Vaka, M.R.; Roiha, I.S.; Lunestad, B.T.; Lindseth, C.; Skipnes, D. Assessment of Food Quality and Microbial Safety of Brown Macroalgae (Alaria Esculenta and Saccharina Latissima). J. Sci. Food Agric. 2019, 99, 1198-1206. [CrossRef]

33. Ho, K.K.H.Y.; Redan, B.W. Impact of Thermal Processing on the Nutrients, Phytochemicals, and Metal Contaminants in Edible Algae. Crit. Rev. Food Sci. Nutr. 2020, 1-19. [CrossRef]

34. Rajauria, G.; Jaiswal, A.K.; Abu-Ghannam, N.; Gupta, S. Effect of Hydrothermal Processing on Colour, Antioxidant and Free Radical Scavenging Capacities of Edible Irish Brown Seaweeds. IFST 2010, 45, 2485-2493. [CrossRef]

35. Mateluna, C.; Figueroa, V.; Ortiz, J.; Aguilera, J.M. Effect of Processing on Texture and Microstructure of the Seaweed Durvillaea Antarctica. J. Appl. Phycol. 2020, 32, 4211-4219. [CrossRef]

36. Cox, S.; Gupta, S.; Abu-Ghannam, N. Application of Response Surface Methodology to Study the Influence of Hydrothermal Processing on Phytochemical Constituents of the Irish Edible Brown Seaweed Himanthalia Elongata. Bot. Mar. 2011, 54, 471-480. [CrossRef]

37. Poojary, M.M.; Barba, F.J.; Aliakbarian, B.; Donsì, F.; Pataro, G.; Dias, D.A.; Juliano, P. Innovative Alternative Technologies to Extract Carotenoids from Microalgae and Seaweeds. Mar. Drugs. 2016, 14, 214. [CrossRef]

38. Domínguez-González, R.; Moreda-Piñeiro, A.; Bermejo-Barrera, A.; Bermejo-Barrera, P. Application of Ultrasound-Assisted Acid Leaching Procedures for Major and Trace Elements Determination in Edible Seaweed by Inductively Coupled Plasma-Optical Emission Spectrometry. Talanta 2005, 66, 937-942. [CrossRef]

39. Muniz-Naviero, O.; Moreda-Pineiro, A.; Bermejo-Barrera, A.; Bermejo-Barrera, P. AAS Determination of Total Arsenic and Toal Inorganic Arsenic in Seaweed After High-Temperature Ultrasound-Assisted Extraction. At. Spectrosc. 2004, $25,79-87$.

40. Romarís-Hortas, V.; Moreda-Piñeiro, A.; Bermejo-Barrera, P. Microwave Assisted Extraction of Iodine and Bromine from Edible Seaweed for Inductively Coupled Plasma-Mass Spectrometry Determination. Talanta 2009, 79, 947-952. [CrossRef]

41. Romarís-Hortas, V.; Bermejo-Barrera, P.; Moreda-Piñeiro, A. Ultrasound-Assisted Enzymatic Hydrolysis for Iodinated Amino Acid Extraction from Edible Seaweed before Reversed-Phase High Performance Liquid Chromatography-Inductively Coupled Plasma-Mass Spectrometry. J. Chromatogr. A. 2013, 1309, 33-40. [CrossRef]

42. Wang, X.; Xu, J.; Wang, L.; Gao, X.; Fu, X.; Zhao, Y. Optimization of Microwave-Ultrasound-Assisted Enzymatic Hydrolysis Extraction of Iodine Amino Acids in Laminaria by High Performance Liquid Chromatography with a Photodiode Array Detector. Algal. Res. 2019, 39, 101452. [CrossRef]

43. Charoux, C.M.G.; O'Donnell, C.P.; Tiwari, B.K. Chapter 9-Ultrasound Processing and Food Quality. In Ultrasound: Advances for Food Processing and Preservation; Bermudez-Aguirre, D., Ed.; Academic Press: Cambridge, MA, USA, 2017; pp. 215-235. ISBN 978-0-12-804581-7.

44. Zhang, Z.-H.; Wang, L.-H.; Zeng, X.-A.; Han, Z.; Brennan, C.S. Non-Thermal Technologies and Its Current and Future Application in the Food Industry: A Review. IJFST 2019, 54, 1-13. [CrossRef]

45. Astráin-Redín, L.; Ciudad-Hidalgo, S.; Raso, J.; Condón, S.; Cebrián, G.; Álvarez, I. Application of High-Power Ultrasound in the Food Industry I IntechOpen. In Sonochemical Reactions; Karakuş, S., Ed.; IntechOpen: London, UK, 2019; pp. $103-126$.

46. Condón-Abanto, S.; Raso, J.; Arroyo, C.; Lyng, J.G.; Condón, S.; Álvarez, I. Evaluation of the Potential of Ultrasound Technology Combined with Mild Temperatures to Reduce Cadmium Content of Edible Crab (Cancer Pagurus). Ultrason. Sonochem. 2018, 48, 550-554. [CrossRef]

47. Zhou, J.L.; Huang, P.L.; Lin, R.G. Sorption and Desorption of $\mathrm{Cu}$ and Cd by Macroalgae and Microalgae. Environ. Pollut. 1998, 101, 67-75. [CrossRef]

48. Gall, E.A.; Küpper, F.C.; Kloareg, B. A Survey of Iodine Content in Laminaria Digitata. Bot. Mar. 2004, 47, 30-37. [CrossRef]

49. MacArtain, P.; Gill, C.I.R.; Brooks, M.; Campbell, R.; Rowland, I.R. Nutritional Value of Edible Seaweeds. Nutr. Rev. 2007, 65, 535-543. [CrossRef]

50. Nitschke, U.; Ruth, A.A.; Dixneuf, S.; Stengel, D.B. Molecular Iodine Emission Rates and Photosynthetic Performance of Different Thallus Parts of Laminaria Digitata (Phaeophyceae) during Emersion. Planta 2011, 233, 737-748. [CrossRef]

51. Schiener, P.; Black, K.D.; Stanley, M.S.; Green, D.H. The Seasonal Variation in the Chemical Composition of the Kelp Species Laminaria Digitata, Laminaria Hyperborea, Saccharina Latissima and Alaria Esculenta. J. Appl. Phycol. 2015, 27, 363-373. [CrossRef]

52. Villare, R.; Puente, X.; Carballeira, A. Seasonal Variation and Background Levels of Heavy Metals in Two Green Seaweeds Environ. Pollut. 2002, 119, 79-90. [CrossRef]

53. Hwang, Y.O.; Park, S.G.; Park, G.Y.; Choi, S.M.; Kim, M.Y. Total Arsenic, Mercury, Lead, and Cadmium Contents in Edible Dried Seaweed in Korea. Food. Addit. Contam. Part B Surveill 2010, 3, 7-13. [CrossRef]

54. Maehre, H.K.; Malde, M.K.; Eilertsen, K.-E.; Elvevoll, E.O. Characterization of Protein, Lipid and Mineral Contents in Common Norwegian Seaweeds and Evaluation of Their Potential as Food and Feed. J. Sci. Food. Agric. 2014, 94, 3281-3290. [CrossRef]

55. Yamada, M.; Yamamoto, K.; Ushihara, Y.; Kawai, H. Variation in Metal Concentrations in the Brown Alga Undaria Pinnatifida in Osaka Bay, Japan. Phycol. Res. 2007, 55, 222-230. [CrossRef]

56. Desideri, D.; Cantaluppi, C.; Ceccotto, F.; Meli, M.A.; Roselli, C.; Feduzi, L. Essential and Toxic Elements in Seaweeds for Human Consumption. J. Toxicol. Environ. Health. A 2016, 79, 112-122. [CrossRef] 
57. Ronan, J.M.; Stengel, D.B.; Raab, A.; Feldmann, J.; O’Hea, L.; Bralatei, E.; McGovern, E. High Proportions of Inorganic Arsenic in Laminaria Digitata but Not in Ascophyllum Nodosum Samples from Ireland. Chemosphere 2017, 186, 17-23. [CrossRef] [PubMed]

58. Taylor, V.F.; Jackson, B.P. Concentrations and Speciation of Arsenic in New England Seaweed Species Harvested for Food and Agriculture. Chemosphere 2016, 163, 6-13. [CrossRef] [PubMed]

59. World Health Organization. WHO Technical Report Series 95-Evaluation of Certain Contaminants in Food: Seventy-Second Report of the Joint FAO/WHO Expert Committee in Food Additives; WHO: Geneva, Switzerland, 2011.

60. Rose, M.; Lewis, J.; Langford, N.; Baxter, M.; Origgi, S.; Barber, M.; MacBain, H.; Thomas, K. Arsenic in Seaweed-Forms, Concentration and Dietary Exposure. Food. Chem. Toxicol. 2007, 45, 1263-1267. [CrossRef] [PubMed]

61. Hughes, M.F. Arsenic Toxicity and Potential Mechanisms of Action. Toxicol. Lett. 2002, 133, 1-16. [CrossRef]

62. Almela, C.; Algora, S.; Benito, V.; Clemente, M.J.; Devesa, V.; Súñer, M.A.; Vélez, D.; Montoro, R. Heavy Metal, Total Arsenic, and Inorganic Arsenic Contents of Algae Food Products. J. Agric. Food Chem. 2002, 50, 918-923. [CrossRef] [PubMed]

63. CEVA. Edible Seaweed and Microalgae-Regulatory Status in France and Europe; CEVA: Pen Lan Peninsula, France, 2014.

64. AFSSA. Opinion of the French Food Safety Agency on the Recommended Maximum Inorganic Arsenic Content of Laminaria and Consumption of These Seaweeds in Light of Their High Iodine Content; AFSSA: Austin, TX, USA, 2009.

65. Cherry, P.; O’Hara, C.; Magee, P.J.; McSorley, E.M.; Allsopp, P.J. Risks and Benefits of Consuming Edible Seaweeds. Nutr. Rev. 2019, 77, 307-329. [CrossRef]

66. ANSES. OPINION of the French Agency for Food, Environmental and Occupational Health E Safety on the Risk of Excess Iodine Intake from the Consumption of Seaweed in Foodstuffs; ANSES Opinion Request No 2017-SA-0086; ANSES: Buenos Aires, Argentina, 2018.

67. Monteiro, M.S.; Sloth, J.; Holdt, S.; Hansen, M. Analysis and Risk Assessment of Seaweed. EFSA J. 2019, 17, e170915. [CrossRef]

68. European Food Safety Authority (EFSA) Scientific Opinion on Dietary Reference Values for Iodine. EFSA Panel on Dietetic Products, Nutrition and Allergies (NDA). EFSA J. 2014, 12, 3660.

69. Zava, T.T.; Zava, D.T. Assessment of Japanese Iodine Intake Based on Seaweed Consumption in Japan: A Literature-Based Analysis. Thyroid Res. 2011, 4, 14. [CrossRef] [PubMed]

70. Raize, O.; Argaman, Y.; Yannai, S. Mechanisms of Biosorption of Different Heavy Metals by Brown Marine Macroalgae. Biotechnol. Bioeng. 2004, 87, 451-458. [CrossRef] [PubMed]

71. Lomax, C.; Liu, W.-J.; Wu, L.; Xue, K.; Xiong, J.; Zhou, J.; McGrath, S.P.; Meharg, A.A.; Miller, A.J.; Zhao, F.-J. Methylated Arsenic Species in Plants Originate from Soil Microorganisms. New Phytol. 2012, 193, 665-672. [CrossRef]

72. Güven, K.C.; Akyüz, K.; Yurdun, T. Selectivity of Heavy Metal Binding by Algal Polysaccharides. Environ. Toxicol. Chem. 1995, 47, 65-70. [CrossRef]

73. Henriques, B.; Teixeira, A.; Figueira, P.; Reis, A.T.; Almeida, J.; Vale, C.; Pereira, E. Simultaneous Removal of Trace Elements from Contaminated Waters by Living Ulva Lactuca. Sci. Total Environ. 2019, 652, 880-888. [CrossRef] [PubMed]

74. Hou, X.; Chai, C.; Qian, Q.; Yan, X.; Fan, X. Determination of Chemical Species of Iodine in Some Seaweeds (I). Sci. Total Environ. 1997, 204, 215-221. [CrossRef]

75. Küpper, F.C.; Carpenter, L.J.; McFiggans, G.B.; Palmer, C.J.; Waite, T.J.; Boneberg, E.-M.; Woitsch, S.; Weiller, M.; Abela, R.; Grolimund, D.; et al. Iodide Accumulation Provides Kelp with an Inorganic Antioxidant Impacting Atmospheric Chemistry. PNAS 2008, 105, 6954-6958. [CrossRef] [PubMed]

76. Seymour, I.J.; Burfoot, D.; Smith, R.L.; Cox, L.A.; Lockwood, A. Ultrasound Decontamination of Minimally Processed Fruits and Vegetables. IFST 2002, 37, 547-557. [CrossRef]

77. Knorr, D.; Zenker, M.; Heinz, V.; Lee, D.-U. Applications and Potential of Ultrasonics in Food Processing. Trends Food Sci. Technol. 2004, 15, 261-266. [CrossRef]

78. Chemat, F.; Rombaut, N.; Sicaire, A.-G.; Meullemiestre, A.; Fabiano-Tixier, A.-S.; Abert-Vian, M. Ultrasound Assisted Extraction of Food and Natural Products. Mechanisms, Techniques, Combinations, Protocols and Applications. A Review. Ultrason. Sonochem. 2017, 34, 540-560. [CrossRef]

79. Di Palma, L.; Mecozzi, R. Heavy Metals Mobilization from Harbour Sediments Using EDTA and Citric Acid as Chelating Agents. J. Hazard. Mater. 2007, 147, 768-775. [CrossRef]

80. Rahman, M.A.; Hasegawa, H.; Ueda, K.; Maki, T.; Rahman, M.M. Influence of EDTA and Chemical Species on Arsenic Accumulation in Spirodela Polyrhiza L. (Duckweed). Ecotoxicol. Environ. Saf. 2008, 70, 311-318. [CrossRef]

81. Hasselström, L.; Visch, W.; Gröndahl, F.; Nylund, G.M.; Pavia, H. The Impact of Seaweed Cultivation on Ecosystem Services-A Case Study from the West Coast of Sweden. Mar. Pollut. Bull. 2018, 133, 53-64. [CrossRef] [PubMed] 